\title{
DEVELOPMENT OF THE PKN LEARNING ATTITUDE ASSESSMENT MODEL IN FOREIGN POLITICAL CULTURE AND RESULTS OF PKN LEARNING FROM STUDENTS OF DEPOK CITY VOCATIONAL SCHOOL(SMK SEMESTA CIMANGGIS)
}

\author{
Sri Rahayu Pudjiastuti ${ }^{\text {a) }}$, Sri Rumiati ${ }^{\text {a) }}$

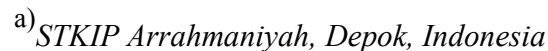 \\ Corresponding Author: yayu.pudjiastuti@gmail.com
}

Article history: received 27 January 2019; revised 15 February 2019; accepted 21 February 2019

\begin{abstract}
This study aims to develop a PKn learning attitude assessment model in shaping the political culture and PKn learning outcomes form students of Depok City Vocational School (SMK Semesta Cimanggis). This research method uses the Research and Development (R\&D). Data analysis is done to see the value of each aspect or descriptor on the questionnaire. Material experts validate one time, this is caused by the average score of the results of material validation which shows a value of 3.61 which is in the good category so that the PKn learning attitude assessment model has met the standards to be tested.The evaluation expert validates twice, this is due to the average score of the results of the evaluation of stage I evaluators still showing a value of 3.35 which included enough categories so that they did not meet the standards for testing. The model of the PKn Learning Attitude assessment model was subsequently revised according to the material expert's recommendations and comments, and the revised PKn attitude learning evaluation model was revalidated by the expert evaluation Validation by evaluation experts in Phase II showed a mean score of 3.7 which belongs to the category well. Based on these results the model of PKn learning attitude assessment is worthy of being tested. Based on interviews with teachers and students, the model of PKn learning attitude assessment was revised again. The results of revision II produced the final product model for assessing PKn' learning attitudes with democratic culture material.
\end{abstract}

Keywords: Model of attitude assessment, Political culture.

\section{INTRODUCTION}

Assessment of learning outcomes is one of the activities in the world of education that is very important. A standard procedure is an assessment procedure that is carried out using certain steps and fair treatment for students by considering the situation of time, place, and variety of diversity in students. While the standard instrument is an instrument that is prepared using standard instrument development procedures and can be accounted for the level of validity and reliability [1].

Assessment carried out to shape the political culture and learning outcomes of the student PKn only focuses on knowledge or skills, there are still many students whose grades of report cards are not in accordance with the reality that exists in society, in this case related to the existence of a growing political culture in society. It is expected that the development of PKn learning learning models can increase student credibility in the community.

\section{Itself Attitude Assessment}

Attitude assessment is an assessment carried out by observing the attitude of students in behaving within the learning environment. The attitude starts from feeling like or disliking related to the tendency of someone to act in response to something / object. Attitudes are also expressions of values or views of life that are owned by someone. Attitudes can be formed for the occurrence of desired behaviors or actions. The objects of attitude that need to be assessed in the learning process of various subjects are as follows; (1) attitude towards subject matter. (2) attitude towards the teacher. (3) Attitudes towards the learning process. (4) Attitudes related to certain values or norms related to a subject matter. (5) other attitudes contained in the purpose of education. For example; independent, creative, responsible, democratic [2]. Attitude assessment can be used by teachers to be able to evaluate more objectively and fairly. Teachers need to have skills in using Attitude Valuation, in addition to ability in test techniques. Attitude assessment techniques and tools are: (1) observation, (2) event record, (3) questionnaire or questionnaire (4) interview /interview, (4) checklist, or choice scale, (5) sociometry; (6) collection of personal notes of students, and (7) case studies.

The form and type of evaluation assessing attitude in applying it in class is very dependent on the character of the material or subject matter / sub-subject to be taught. So not every material can be implemented assessment attitude. Therefore the accuracy and thoroughness of a teacher to develop appropriate forms 
of non-test assessment is very necessary. However, as a handle in forming and the type of evaluation we can review the opinions of Wayan Wida who put forward considerations in determining the type of assessment tool, namely; (1) Aspects of ability to be assessed, such as cognitive, and psychomotor, (2) The nature of the material we will present, (3) The size of the group to be tested, (4) Frequency of use of assessment tools, (5) Teacher opportunities for correction [3]

Based on the above Theoretical Study, the attitude assessment synthesis is a valuation conducted by observing the attitudes of learners in the behavior of the place of study, the object of the attitude to be assessed is; attitudes toward subject matter, attitudes towards teachers, attitudes toward learning process, attitude toward values and norms.

\section{Political Culture}

According to Moctar massoed, the definition of political culture is the attitude and orientation of a citizen of a country towards the life of state and political government [4]. Political culture is a pattern of behavior of a society in the life of the state, the administration of state administration, government politics, law, norms of habit that are shared by all members of society every day. Political culture can also be interpreted as a system of values together with a society that has the awareness to participate in collective decision making and determination of public policy for the whole community [5].

Characteristics of political culture [5]; (1) there are power arrangements, (2) behavior of state apparatus, (3) government policy-making processes, (4) the existence of political party activities, (5) the existence of community turmoil towards the ruling power, (6) regarding allocation patterns community sources. (7) the existence of a political culture on the issue of legitimacy [6].

Gabriel A. Almond and Sidney Verba associate political culture with one's political orientation and attitude towards the political system. There are three components, namely: Cognitive Component, namely the ability that concerns the level of knowledge and understanding as well as the beliefs and beliefs of a santri on the course of the political system and its attributes [7]. There are several types of politics in Indonesia, caused by several factors, namely as follows; (1) the diversity that grows in Indonesian society. (2) the people who adhere to the parochial culture are caused by isolation from outside culture, the influence of colonialism, feudalism, paternalistic (fatherly) and primordial ties. As for those who embrace the participants influenced by the level of education. (3) The nature of primordial bonds has the characteristics of regional, ethnic, and religious sentiments. (4) the tendency of Indonesian political culture which still affirms the attitude of paternalism, and the patrimonial nature (inheritance of the father),
(5) the interaction dilemma regarding modernization with patterns that have long been rooted in tradition in society [8].

Political culture in Indonesia is an embodiment of the values adopted by the Indonesian people as a guideline for state political activities. At present Indonesian political culture is a mixture of parochial, religious and participant because in Indonesia there are parochial characteristics and characteristics of the political culture of participants [9].

Based on the description of the theory above, the synthesis of student learning outcomes about political culture is the ability of students in cognitive, affective and psychomotor, with indicators; (1) understanding of political culture, (2) kinds of political culture, (3) political participation, (4) functions of political parties, (5) implementation of political culture.

\section{RESEARCH METHODS}

The research approach used in this study is the Research and development (R\&D) method. The research was conducted over a period of three months from August to October 2018, held at SMK Semesta Cimanggis Jln Raya Bogor Km 33.5 No.40. the subject of the evaluation model of the attitude of PKn's learning attitude in Vocational High School class XI were two expert evaluation experts and material experts. The technique of collecting data is through observation, interviews, documents and questionnaires

\section{RESULTS AND DISCUSSION}

The average score calculation of the data obtained aims to determine the feasibility of the model of PKn Learning attitude assessment for learning PKn in Vocational High School Grade XI. The results of the validation obtained are compared with the categories according to Eko Putro [10].

\section{Results of Validation}

The average score calculation of the data obtained aims to determine the feasibility of the model of PKn Learning attitude assessment for learning PKn in Vocational High School Grade XI. The results of the validation obtained are compared with the categories according to Eko Putro [10].

\section{a. Results of Material Expert Validation}

There are 23 statements in the material expert validation sheet. Material experts validate once. Based on the data it can be seen that the number of scores obtained is 83 with a percentage of $72 \%$, and the average score is 3.61 with the category "good" and the ideal average is 69 and the ideal standard deviation is 15.33. Based on these calculations can be made the conversion of the material expert validation score as follows; 
Tabel 1. Konversi Skor Validasi Ahli materi.

\begin{tabular}{|l|l|l|}
\hline \multicolumn{1}{|c|}{ Rentang Skor } & \multicolumn{1}{c|}{ Rerata Skor } & \multicolumn{1}{c|}{ Kategori } \\
\hline$X>96,59$ & $X>4,2$ & Sangat Baik \\
\hline $78,20<X \leq 96,59$ & $3,4<X \leq 4,2$ & Baik \\
\hline $59,80<X \leq 78,20$ & $2,6<X \leq 3,4$ & Cukup \\
\hline $41,40<X \leq 59,80$ & $1,8<X \leq 2,6$ & Kurang \\
\hline$X \leq 41,40$ & $X \leq 1,8$ & $\begin{array}{l}\text { Sangat } \\
\text { Kurang }\end{array}$ \\
\hline
\end{tabular}

\section{Source: Primary Data Processed}

Model validation of attitude assessment by material experts is done once. The validation by material experts aims to make the product model of PKn Learning attitude assessment developed into a quality product in material aspects, learning and language. The results of calculating the validation in each aspect can be seen in table 2 .

Table 2. Results of Material Expert Validation on Each Aspect

\begin{tabular}{|l|l|l|}
\hline \multicolumn{1}{|c|}{ No } & \multicolumn{1}{|c|}{ Aspek yang Dinilai } & \multicolumn{1}{c|}{ Skor yang Diperoleh } \\
\hline 1 & Materi & 33 \\
\hline 2 & Pembelajaran & 30 \\
\hline 3 & Bahasa & 20 \\
\hline Jumlah & 83 \\
\hline Rentang Skor & $78,20<\mathrm{X} \leq 96,54$ \\
\hline Rerata Skor & 3,61 \\
\hline Kategori Skor & Baik \\
\hline
\end{tabular}

Source: Primary Data Processed

The average final score of material expert validation was 3.61 in the $\mathrm{Mi}+0.6 \mathrm{Sbi}<\mathrm{Mi}+1.8 \mathrm{Sbi}$ range with an average of $3.4<\mathrm{X} 24.2$ or the category "good. Based on these results, it can be seen that the attitude assessment model developed is feasible to be used in aspects of learning and language.

\section{b. Results of Validation of Evaluation Experts}

There are 20 statements in the evaluation expert validation sheet. Based on the data it can be seen the results of stage I evaluation expert validation show the results of the total score of 67 with a percentage of $67 \%$, and the average score of 3.35 with the category "enough". In the validation of stage II evaluation experts showed the results of a total score of 74 with a percentage of $74 \%$, and the average score of 3.7 in the "good" category, and the ideal average was 60 and the ideal standard deviation was 13.33. Based on the calculation, the conversion of the evaluation expert's validation score can be made as follows:

Tabel 3. Konversi Skor Validasi Ahli Evaluasi

\begin{tabular}{|l|l|l|}
\hline Rentang Skor & Kategori & Kategori \\
\hline$X>83,99$ & $X>4,2$ & Sangat Baik \\
\hline $67,98<X \leq 83,99$ & $3,4<X \leq 4,2$ & Baik \\
\hline $52,02<X \leq 67,98$ & $2,6<X \leq 3,4$ & Cukup \\
\hline $36,06<X \leq 52,02$ & $1,8<X \leq 2,6$ & Kurang \\
\hline$X \leq 36,06$ & $X \leq 1,8$ & Sangat Kurang \\
\hline
\end{tabular}

Source: Primary Data Processed
Validation evaluation by expert evaluation is done twice. Validation by evaluation experts aims to make the product model of PKn Learning attitude assessment developed into a quality product. The results of calculating the validation in each aspect can be seen in the following table;

Table 4. Results of Expert Validation Evaluation on Each Aspect

\begin{tabular}{|l|l|l|l|}
\hline \multirow{2}{*}{ No } & \multirow{2}{*}{$\begin{array}{c}\text { Aspek yang } \\
\text { Dinilai }\end{array}$} & \multicolumn{2}{|c|}{ Tkor yang Diperoleh } \\
\cline { 3 - 4 } & Tahap I & \multicolumn{1}{|c|}{ Tahap II } \\
\hline 1 & Pemrograman & 9 & 12 \\
\hline 2 & Tampilan & 58 & 62 \\
\hline Jumlah & 67 & 74 \\
\hline Rentang Skor & $52,02<\mathrm{X} \leq 67,98$ & $67,98<\mathrm{X} \leq 83,94$ \\
\hline Rerata Skor & 3,35 & 3,7 \\
\hline Kategori Skor & Cukup & Baik \\
\hline
\end{tabular}

Source: Primary Data Processed

\section{CONCLUSION}

The PKn learning attitude assessment model helps students focus more on learning. This can be seen from the attention of students when the teacher is delivering material. The attitude assessment model can arouse student motivation, and help students think critically. This can be seen from the comments and responses of students regarding the material presented. The use of the PKn learning attitude assessment model can also simplify the teacher's task in presenting material and evaluating according to the 2013 curriculum.

\section{REFERENCES}

[1] Elly Herliani. 2009. "Penilaian Hasil Belajar". Ebooks. Bandung: PPPPTK IPA di download melaluihttp://www.slideshare.net/NASuprawoto /penilaian-hasil-belajar/download

[2] Maharani,Fauzan A., Cara Penilaian Sikap attitude siswa. Diunduh; Sabtu, 17 Agustus 2013

[3] Wayan Wida (1984), Evaluasi Hasil Belajar PMP, Jakarta: , P2LPTK Dikti Depdikbud.

[4] Lubis, M. Solly, 1993. Ketatanegaraan Republik Indonesia, Bandung: Mandar Maju.

[5] Magnis Suseno, Frans. 2001.Etika Politik. Jakarta; Gramedia.

[6] Ndraha, Taliziduhu, 2003. Kybernologi: Ilmu Pemerintahan Baru. Penerbit PT Rineka Cipta: Jakarta.

[7] Almon;Gabriel A. and Bingham Powell, Comprative Politic A Developmental Approach dikutip

[8] Mardjono, Hartono; 1997. Politik Indonesia, Jakarta: Gema Insani Press. 
[9] Muhaimin, Yahya. Collin Mc Andrew. 1995, Masalah-Masalah Pembangunan Politik. Yogyakarta: Gajah Mada University Press.

[10] Eko Putro Widoyoko,S. 2009. Evaluasi Program Pembelajaran. Yogyakarta: Pustaka Pelajar. 